\title{
A Comparative Study for Pre and Post War Performance of Colombo Stock Exchange (CSE)
}

\section{A. I. Dayaratne}

Department of Accountancy \& Finance, Faculty of Management Studies, Sabaragamuwa University of Sri Lanka. indunil@sab.ac.lk

\begin{abstract}
It is currently debated in academic and other forums that the peace dawning in the country has induced the performance of CSE in Sri Lanka. It is invariably accepted that the smooth functioning of the stock market is largely determined by the stability of the country's business environment. Thus, this paper attempts to explore whether there is an improvement in the performance of the each business sector listed on CSE in the post war periods. For the purpose of separately highlighting the impact of peace on stock market performance some pre war periods are also considered. The period 2005 to 2008 is considered as pre war period and the period 2009 to 2012 is considered as post war period. To measure the performance of the CSE some important indicators were used namely, sector indexes, market capitalization of the companies, foreign purchases and sales and total turnover of the CSE and key market ratios. Perhaps importantly, these indicators are very widely used in measuring stock market performance by practitioners and academics in developed and developing markets. It is established that majority of the performance indicators used in this study are highly sensitive to the peaceful dividend in the country. Moreover, it is found that majority of indicators have gained significant improvement after the war. The findings imply that peace is an essential element for the development of the capital market in Sri Lanka.
\end{abstract}

Key Words: Market Performance, Pre and Post war, Price Earnings, Book to Market,

\section{Introduction}

It is generally believed that among the key drivers of the economy in a country, the activities of the capital market play a vital role. Smooth functioning of the capital market is essentially important in achieving the intended benefits of the capital markets as well as for the development of the economy as a whole. However, due to turmoil situation in the country during the last three decades, there has been conflicting views among the people in different ${ }^{1}$ segments of the society. Some are of the view that the CSE has not performed at its desired level during the war period in the country. Nowadays the environment of the country is peaceful and conducive for the business community to make business decisions in a greater confidence. In the post war episode, the country 
is now in a phase of huge investment in the infrastructure development. Perhaps important projects such as ports and airports provide significant impact on the business environment in the country both in short run and long run. The infrastructure is vital constituent in the process of enhancing the investor confidence. The most widely recognized determinant of the investor confidence is the performance of the capital market in the county. Since 1999 people are getting the benefit of peace regardless of the ethnicity and religion. Now it is reasonably, the ample time to investigate the impact of peaceful environment on the performance of the stock market and for the business community. Thus, this paper attempts to investigate whether there is a significant improvement in the performance of the CSE after the war. The investigation mainly focuses on the performance of 22 industries (Business Sectors) listed in the CSE. These sectors cover the entire companies in the stock market in Sri Lanka. Thus, main premise of this paper is to investigate whether these 22 sectors demonstrate significant performance after ending the civil war. Apart from this paper also aims to identify the business industries that have performed well after the war and to explore the reasons for such performance. Whether this hefty gain will continue is an important puzzle among the people in the country and it is important research question which is worthwhile to explore in academic papers.

\section{What determines the stock market performance}

It is well established in the literature that several factors are affecting for the performance of stock markets. Among them the economic and political environment is widely known as the better market performance indicators, see for example Perotti and Van Oijen (2001) and Panetta (2002). Previous researches have attempted to shed lights on the determinants of stock returns widely in developed and emerging markets. See for example Chan, Hamao and Lakonishok (1991), Ball, Kothari and Watts (1993) and Fama and French (1992a). However, the studies directly focused on the performance of stock markets limited in the finance literature. For example, Alexander and Buchholz (1978) examined the relationship between Corporate Social Responsibility (CSR) and market performance in the US market for the period $1970-1974$ and documented that low correlation between CSR and firm performance. On the other hand it is argued that a ratio like $\mathrm{P} / \mathrm{E}$ has significant effect on the stock market performance. For an example Shen (2000) explored that very high price earnings ratio has usually been followed by poor stock market performance. Konar and Cohen (2001) attempted to link the performance of the stock value in the market and the degree of firm's compliance to the environmental laws. They suggest that the companies which adopt the environmental regulations are rewarded than the firms which are not adopting the compliance measures. Pagano (1993) argues that the stock market performance and the economic 
growth follow a positive relationship. During the war period the economic growth rates was comparatively low as a result the pre war period the stock market performance also remained very low in Sri Lanka ${ }^{1}$. The Capital market sources suggest that after the war Sri Lanka has achieved its ever highest growth rate in 2012 which is $8.6 \%$. This very noticeably reveals that stock market growth and economic growth moving together. Further, Levine and Zervos (1996) examined existence of association between stock market development and economic growth and documented that stock market development is positively and robustly associated with the long run growth. The previous research evidence based on CSE which forcuses on civil war is now emerging in the finance litreture. For example, Abeysekara (2011) examined the effect of current period intellectual capital disclosure on earning and current annual stock returns during civil war and documented that firms do not include current period intellectual capital disclosure in the current stock returns.

\section{Brief Overview of Sri Lankan Stock Market}

The commencement of Share trading in Sri Lanka is linked with the plantation industry in the British Colonial period. After the "coffee blight" the British planters required funds to replace the coffee plantations in Sri Lanka with tea plantations. This led to the setting up of the Colombo Share Brokers Association (CSBA) which commenced trading of shares in limited liability companies in 1896. In 1985, the Colombo Stock Exchange (CSE) was set up as a company which took over these operations from the $\mathrm{CSBA}^{2}$.

The statistics suggest that CSE is one of the smallest stock markets in the world in terms of turnover, the capitalization and the number of trades. Currently the number of companies listed in the CSE is $287^{3}$. The number of investors in the market is around 130,000. However, among these the number of active investors who trade frequently is less than 40,000. The stocks in the CSE are classified into 22 sectors as plantation, banking and finance, manufacturing, tourism etc. The overall market performance is measured by the All Share Price Index (ASPI) and the performance of the industries is measured by the sector indexes.

\section{Current Status of the Performance}

At the end of 2012 the total market capitalization of the market was Rs.2.2 trillion and as previously mentioned the number of listed companies is amounting to $287^{4}$. It also reports that market turnover to market capitalization was $9.8 \%$. There seems to be more investors engaged in trading in the market during the period 2012, there are 702838 Central Depositary Accounts (CDS) and 64792 active investors. The net foreign purchases and sales in 2012 was 
37 billion. On other hand the ASPI has gained only 1400 points for the periods 1985 to 2008, however, after the war it has gained 4250 points in 3 and 1/2 years. This is mainly designated due to the peace dividend. Interestingly, after the year 2008 there is a clear evidence of foreign participation in the market according to the CSE sources it was $24.90 \%$ in 2012, and when it comes to the first half of 2013 foreign participation has increased up to $49.90 \%$. In investors return perspective, for the period 2009 to 2012 the equity risk premium is on average 42.20 which was on average 21.42 for the period 2002 to $2012^{3}$. The current study looks at more variables under two regimes for several years to see the modalities in pre and post war episodes.

\section{Methods used and Indicators}

For the purpose of measuring the performance in different industries several indicators are adopted in this study. The key performance indicator used is the performance of the sector indexes of all the 22 sectors. The listed companies of the CSE have been organized in homogeneous groups under 22 sectors which represents the entire market. The other performance measure is the market capitalization of all these sectors. The variation of market capitalization is compared during pre and post war periods. This paper also looks at the modalities of the pre and post war of the variables namely, new listing of companies in the stock market, Sector ratios such as dividend yield, P/E ratio and price to book value. Foreign, purchase and sales. Sector trading statistics such as trade number, volume and turnover. Time series plot is applied to see the changes in the indicators during the sample period.

\section{Response of Foreign Investors to pre and Post War}

Significant proportion of investor composition of CSE constitutes from foreign investors both individual and institutional investors. Participation of foreign investors to the market brings various benefits to the market itself and for the economy as well. The market becomes very competitive and prices of the stocks correctly priced when more foreign participants involve in trading in the market. The most important economic benefit is that the economy gets more foreign direct investment (FDI) through capital market which leads to the increase the productively in the economy as public companies' wealth and the asset structure is growing under this condition. Before 2008 the perception on CSE among foreign countries was not favorable due to the ongoing war situation in the country. As a result the international participation to the CSE was very limited. In order to see the impact of peace on the foreign investment this study looks at the behavior of the foreign investor composition during pre and post war periods. 
Total Foreign Purchases and Sales

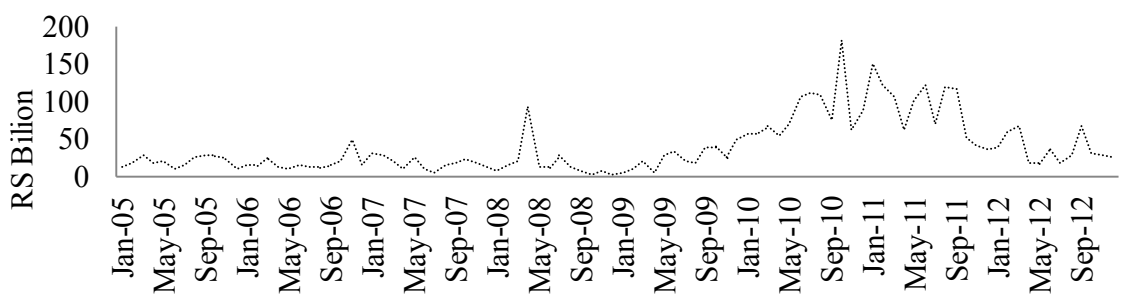

Figure 1: Foreign Purchases and Sales 2005 - 2012

The Figure 1 demonstrates that the after gaining the peace to the country in 1999 there is a phenomenal growth in the foreign investor participation. It was on average around 50 million rupees from 2005 to 2008 under pre war background. During the years 2010 and 2011 it shows more foreign participation in the market ever than before. However, when it comes to 2012 it seems a significant drop in the foreign purchases and sales. The year 2012 was very difficult period for the CSE since it was faced with the politically motivated governance structure. This resulted for the frequent changes in the core governing body of the Securities and Exchange Commission in Sri Lanka.

It is widely accepted fact that the for a smooth running of the stock markets whether in developed counties or developing countries market regulation plays pivotal role in enhancing the investor confidence. The foreign investors are highly sensitive to the economic, social and political development in the country. The weak monitoring and regulating formation may have led for the decline of foreign investors in the market in 2012. It is essential to have transparency in the regulation for a market to perform well. Moreover, during the late 2011 and 2012 international pressure on war crime can lead to lose the investor confidence in the market. The increase of foreign purchase and sales during 2008 to 2001 can be attributable to the peaceful condition in the country, which advocates that that international investors are highly rely on the this phenomena. 


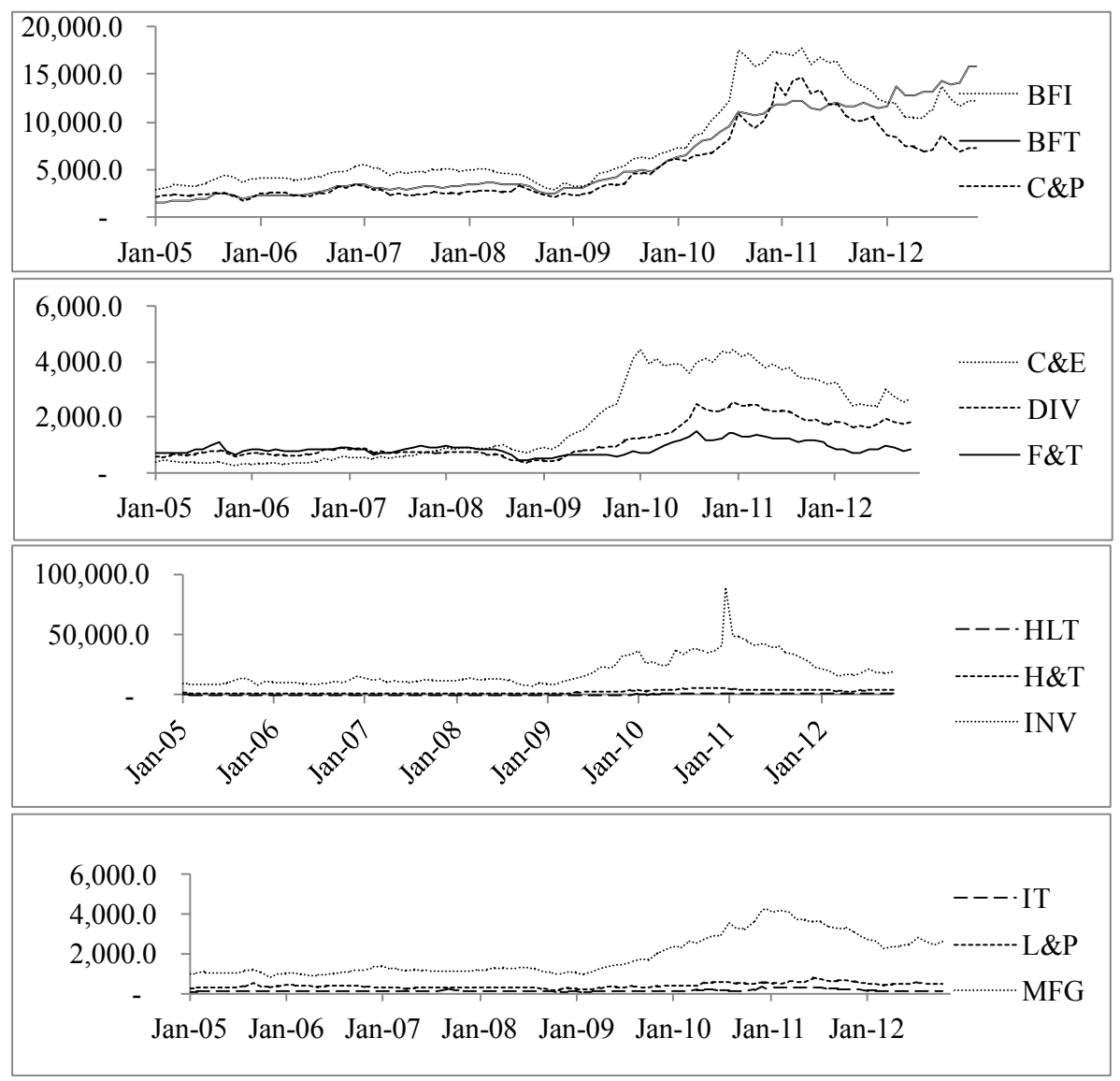

Figure 2(a): Pre and Post war Performance of the Sector Indexes of CSE. The period 2005 to 2008 is considered as the pre war period and the period after 2009 to 2012 is considered as post war period. The line charts show the behavior of the sector indexes. The $\mathrm{X}$ axes represent the January month in each year and the $\mathrm{Y}$ axis represents the index value. The line charts show; [Bank Finance and Insurance (BFI), Beverage Food and Tobacco (BFT), Chemicals and Pharmaceuticals (C\&P), Construction and Engineering (C\&E),Diversified Holdings (DIV),Footwear and Textile (F\&T),Health Care (HLT),Hotels and Travels (H\&T),Information Technology (IT), Investment Trusts (INV),Land and Property (L\&P),Manufacturing (MFG),Motors (MTR), Oil Palms (OIL), Plantations (PLT), Power \& Energy (P\&E),Services (SRV), Stores Supplies (S\&S), Telecommunications (TLE), Trading (TRD)].

Figure 2 demonstrates the behavior of the sector indexes during pre and post war situation. The overall performance of the market is the aggregate performance of each sector. The sector index is the key performance indicator which also represents the performance of several companies listed under the sector. In Figure 2(a) four line charts are combined together for simple presentation and for easy understanding. In each chart three indexes are plotted together. Out of 12 sectors as demonstrated in the Figure 1(a) 8 sectors 
have gained phenomenal growth after the war. It shows that only 4 sectors are not significantly sensitive to the peaceful environment in the country. This finding suggests some important considerations. One has judge whether it is mainly due to the positive sentiments on industry factors or positive sentiments on market factors. Different school of thoughts has conflicting views on that. Lessard (1976) suggested that country factors are dominant in determining the security price return. While Brinson (1998) and Weiss Weiss (1998) have advocated the notion that global industry factors will constitutes an increasingly important dimension of investment strategy. However, the peace creates more avenues for the companies and which leads to enhance the profitability of these companies. The companies then can pay higher dividends and more bonuses to the shareholders which tend to increase the share prices in the market. On the other hand in the market higher prices can attract more investors which lead to more demand for shares and it enhances the share prices in the market.

The Figure 2 very clearly states that due to peaceful environment in the country there has been a remarkable increase in the market. In these circumstances the industry specific factors seems to be minute determinant of the sector performance. The low performance of the stock market in pre war situation can be attributable to investors' negative sentiments. The investor sentiment is the belief of the investors about the future movement of share prices which is negative perception. Conversely, after ending the war the investors got more confidence on the market and have reacted accordingly and created positive sentiment on the market. However, almost all the sectors have declined during 2012 which needs more attention of authorities.

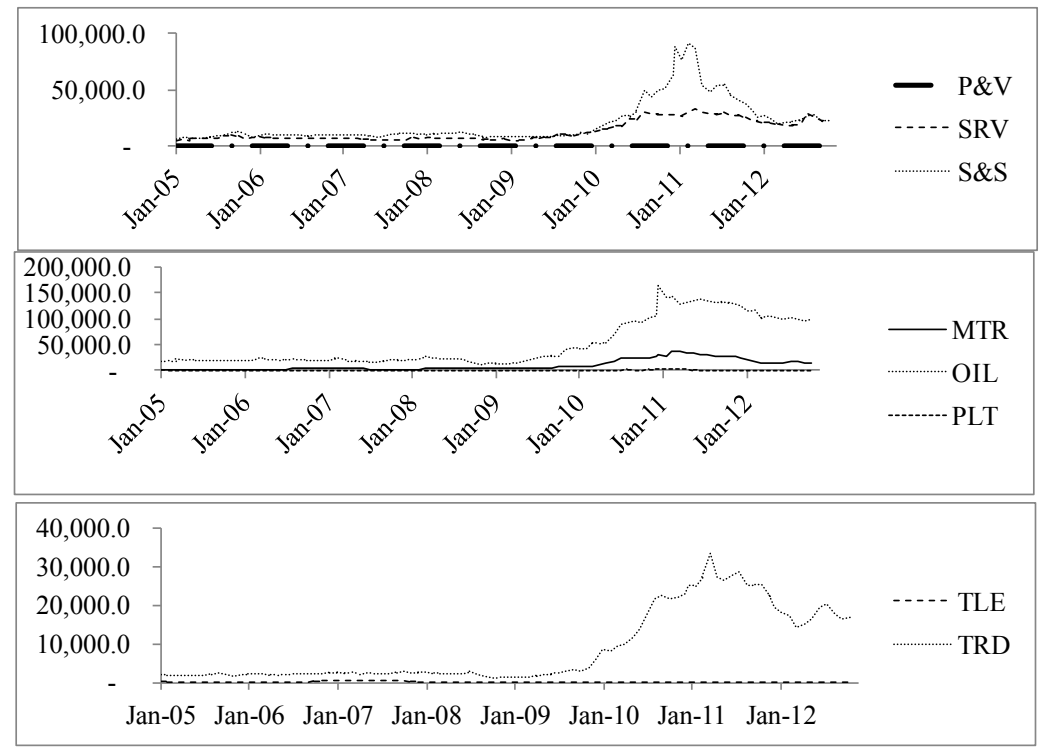

Figure 2 (b): Pre and Post war Performance of the Sector Indexes of CSE. 
Moreover, Figure 2(b) summarizes performances of sector indexes of balance sectors considered in this paper. It demonstrates that out of 8 indexes shown in the Figure 2 (b), only four have exceptionally, performed under a peaceful environment after the war. The MTR sector shows mile response to the peace atmosphere. It is very apparent that in the CSE all the sectors have not responded exponentially to the post war episodes of the country. This is mainly due to the company specific and industry specific risk factors. It suggests that performance of stocks is determined by both firm specific and Marco factors. However, the Sharpe increase of sector indexes immediately after the war signals positive impact of peace on the stock market performance.

\section{Total Market Turnover}

The other important determinant of the performance of the stock market which considered in this paper is the total turnover, of the stock market. The Figure 3 reports that before, 2009 the annual turnover, of the CSE recorded below 200 million. In this period the country had to face the consequence of the expensive civil war. It is well known fact that during this period the key macro economic development indicators such as income level gross domestic investment, banking sector development, private capital follows and stock market liquidity were very weak. The period 2008 to 2010 records very Sharpe increase in turnover. This can be attributable to the peace dividend of the country. It is evidenced that after 2009 more investors have started trading in the market this may be the main reason for the rapid increase in the market turnover during that period. During the year 2011 it remains unchanged and 2012 records Sharpe decline. This Sharpe decline can be caused by the deterioration of the regulatory mechanism of the market due to very frequent change of chairman of the Securities Exchange Commission of Sri Lanka.

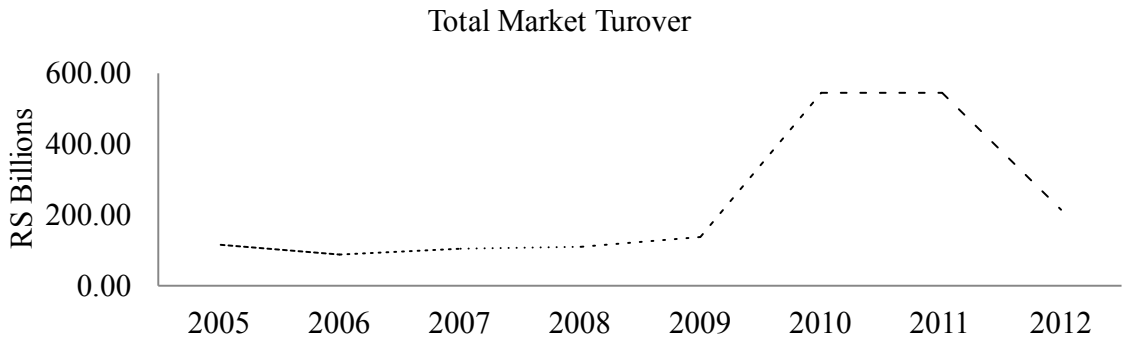

Figure 3: Total Turnover of CSE 2005-2012. The period 2005 to 2008 is considered as pre war and the period 2009 to 2012 represent the post war period.

\section{Market Capitalization}

The Figure 3 shows the annual total market capitalization of all the companies listed on Colombo Stock Exchange. It very clearly shows that there is a 
phenomenal growth of Market capitalization of companies after 2008 which suggests that the peace is very important factor in enhancing the total market capitalization of companies. The rapid increase of the market capitalization is due to the listing of now companies in the capital market. More investors came to the market after the war in the country. However, during the years 2011 and 2012 market capitalization remains constant which suggests that no significant market participation is not taken place. The market can attract more active investors by conducting awareness programmes and by providing the investors more facilities such as internet usage to trade in the market through brokerage firms. Moreover, in Sri Lanka still there are huge potential investors in the rural areas. Therefore, policies should be implemented to capture this potential market to further enhance the market capitalization of the CSE.

Market Capapitalization

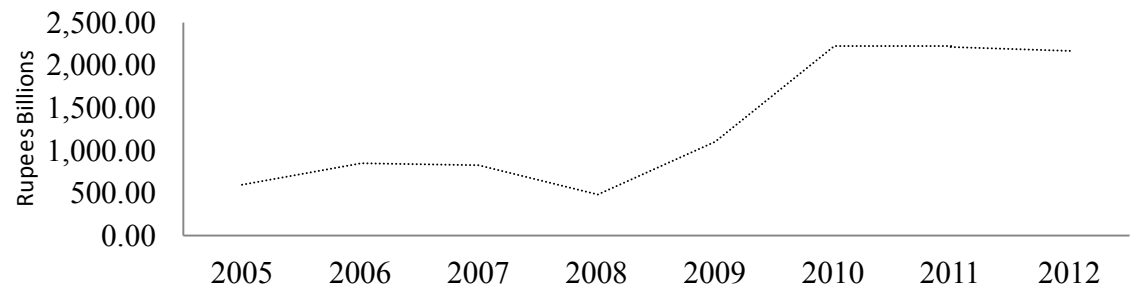

Figure 4: Market Capitalization in Pre and Post war Period. The period 2005 to 2009 is considered as pre war period while the period 2009 to 2012 is considered as post war period. All values are in rupees billions.

Even though the CSE has achieved remarkable growth in market capitalization after the war, it is still far behind in terms of contribution to the Gross Domestic Product (GDP) in comparison to the other countries. Table 1 presents the percentage of market capitalization to GDP in some selected countries similar to Sri Lanka.

Table 1: Country wise comparison of Market Capitalization to GDP.

\begin{tabular}{lc}
\hline \multicolumn{1}{c}{ Country } & $\begin{array}{c}\text { \% of market capitalization } \\
\text { to GDP }\end{array}$ \\
\hline Vietnam & 17 \\
Bangladesh & 29 \\
Sri Lanka & 30 \\
Indonesia & 49 \\
India & 53 \\
Thailand & 77 \\
Philippines & 87 \\
Malaysia & 160 \\
Singapore & 250 \\
\hline
\end{tabular}

Source: CSE sources. 
Previous discussion showed that after the civil war the market capitalization of CSE has gained significant improvement. However, it is very low in Sri Lankan market in relation to the GDP of the countries. As shown in the Table 1 Sri Lanka is ahead only to Vietnam and Bangladesh. It demonstrates that even India is well ahead of Sri Lanka. This suggests that even though CSE has gained a Sharp increase in the market capitalization, it has long way to go to bring to the higher percentage to GDP.

\section{Performance of Market Ratios}

Importantly, financial analysts and practitioners apply market ratios as the determinants of investment performance of the individual companies and whole market. This paper applies some key ratios namely, market price earnings ratio, market price to book value and dividend yield to gage the performance of the CSE in pre war and post war periods. The previous literature such as Banz (1981), Ohlson (1995) suggests that these ratios are very momentous in measuring the stock market performance. However, some studies have invalidated this hypothesis empirically in various markets. For example, Basu (1977) attempted to determine empirically whether the investment performance of common stock is related to their market price to earnings ratio and documented that MPER information was not "fully reflected in security prices.

Moreover, several investigators have attempted to document the validity of Price earnings ratio in different versions. Anderson and Brooks (2006) used decomposed price earning ratio and documented that decomposed MPER constitutes a useful tool for value fund managers and hedge funds. The other important performance indicator is the Market Price to Book Value which has been very widely discussed in the previous literature. The use of book to market value is motivated by the findings of Fama and French (1992b) who demonstrates that book-to-market ratio has the predictive power of the cross sectional returns of the individual stocks. The dividend yield is also applied in this paper as an indicator of the market performance. This also has strong push from the previous evidences for being used in this study. See for example (Fama and French 1988; Nelson and Kim 1993).

Figure 5 demonstrates the performance of the three market indicators during the pre war and post war periods. As show in the Figure 5 Market Price Earnings Ratio (MPER) pre war periods is 12.4 when it comes to post war period it has gained significant improvement which amounts to 17.1. MPER means that how much investor is willing to pay per rupee of earnings. The 17.1 suggests that an investor is willing to pay Rs. 17.1 per one rupee of current earnings. This is because the investors are anticipating higher growth in the future. On the other hand the Market Price to Book Value (PBV) has gained slightly in the post war period. The increase is ranged from 1.7 to 2.0. 
Low PBV suggests that the shares in the market are undervalued. Interestingly, the Dividend Yield (DY) shows slight decline in post war period, from 2.7 to 2.4. DY measures the return to investors for their investment. The findings suggest that the investors have received more dividends in pre war periods than post war periods. However, they have enjoyed form price appreciation in the market and capital gains during the post war period.

\section{Conclusion}

The various analyses conducted in this paper suggest that majority of the sectors in CSE have achieved a remarkable growth after the civil war in Sri Lanka. The performance indicators used in the study has gained predominant growth after 2009 which suggests that peace in the country is vital contributory factor in stock market development. However, it is hardly seen an overall improvements in the market as some sectors do not demonstrate positive response to the peace in the country. The analysis of market ratio contents that in the post war period the dividend yield have declined compared to pre war period. This implies that during post war periods the stock holders have enjoyed capital gains than dividends. The comparison with the other counties reveals that Sri Lanka is still far behind the other similar countries in terms of GDP to market capitalization ratio.

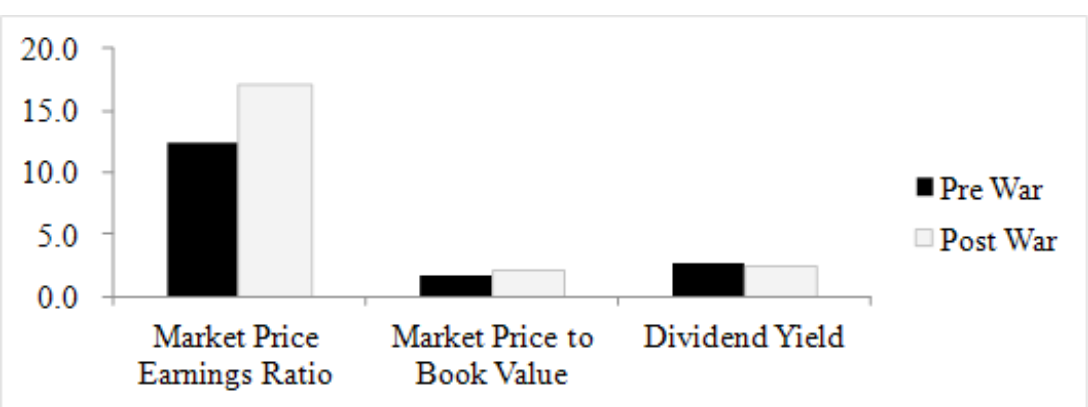

Figure 5: Average Market Ratios during pre and post war periods in CSE. The thick bar represents the average of daily values for the period 2005 to 2008 of the three indicators and the gray bar represents the daily average values of the three indicators for the period 2009 to 2012 .

\section{References}

Alexander, G. J. and R. A. Buchholz (1978) 'Research Notes. Corporate Social Responsibility and Stock Market Performance.' Academy of Management Journal. 21(3). pp. 479-486.

Anderson, K. and C. Brooks (2006) 'Decomposing the Price-Earnings Ratio'. Journal of Asset Management. 6(6). pp. 456-469. 
Ball, R., S. Kothari and R. L. Watts (1993) 'Economic Determinants of the Relation between Earnings Changes and Stock Returns'. Accounting Review. pp. 622-638.

Banz, R. W. (1981) 'The Relationship between Return and Market Value of Common Stocks'. Journal of financial economics. 9(1). pp. 3-18.

Basu, S. (1977) 'Investment Performance of Common Stocks in Relation to Their Priceâ€ arnings Ratios: A Test of the Efficient Market Hypothesis'. The Journal of Finance. 32(3). pp. 663-682.

Brinson, G. (1998) “ "Investment Management in the 21st Century”.' The Future of Investment Management.

Chan, L. K., Y. Hamao and J. Lakonishok (1991) 'Fundamentals and Stock Returns in Japan'. The Journal of Finance. 46(5). pp. 1739-1764.

Fama, E. F. and K. R. French (1988) 'Dividend Yields and Expected Stock Returns'. Journal of Financial Economics. 22(1). pp. 3-25.

Fama, E. F. and K. R. French (1992a) 'The Crossâ€ ection of Expected Stock Returns'. the Journal of Finance. 47(2). pp. 427-465.

Fama, E. F. and K. R. French (1992b) 'The Cross-Section of Expected Stock Returns'. Journal of finance. 47(2). pp. 427-465.

Konar, S. and M. A. Cohen (2001) 'Does the Market Value Environmental Performance?' Review of economics and statistics. 83(2). pp. 281-289.

Lessard, D. R. (1976) 'World, Country, and Industry Relationships in Equity Returns: Implications for Risk Reduction through International Diversification'. Financial analysts journal. pp. 32-38.

Levine, R. and S. Zervos (1996) 'Stock Market Development and Long-Run Growth'. The World Bank Economic Review. 10(2). pp. 323-339.

Nelson, C. R. and M. J. Kim (1993) 'Predictable Stock Returns: The Role of Small Sample Bias'. The Journal of Finance. 48(2). pp. 641-661.

Ohlson, J. A. (1995) 'Earnings, Book Values, and Dividends in Equity Valuation*'. Contemporary accounting research. 11(2). pp. 661-687.

Pagano, M. (1993) 'Financial Markets and Growth: An Overview'. European economic review. 37(2). pp. 613-622.

Panetta, F. (2002) 'The Stability of the Relation between the Stock Market and Macroeconomic Forces'. Economic Notes. 31(3). pp. 417-450.

Perotti, E. C. and P. Van Oijen (2001) 'Privatization, Political Risk and Stock Market Development in Emerging Economies'. Journal of International Money and Finance. 20(1). pp. 43-69. 
Shen, P. (2000) 'The P/E Ratio and Stock Market Performance'. Economic Review-Federal Reserve Bank of Kansas City. 85(4). pp. 23-36.

Weiss, A. (1998) "“Global Industry Rotation: New Look at an Old Idea."”. Financial Analysts Journal,. 54(3(May/June)). pp. 6-8.

\section{Endnotes}

${ }^{1}$ Central Bank Reports 2005 - 2012.

${ }^{2} \mathrm{CSE}$ web site

${ }^{3}$ http://www.cse.lk/home.do. (Last accessed date 2014.06.06).

${ }^{4}$ Data library 2012 CSE.

${ }^{5}$ CSE publications and bulletins for several years 